\title{
Challenges of Dissemination of Islam-related Information for Chinese Muslims in China
}

\section{Tantangan dalam Menyebarkan Informasi terkait Islam bagi Muslim China di China}

\author{
Ting Ma ${ }^{1,2}$, Romlah Ramli², Nik Adzrieman Abdul Rahman ${ }^{2}$ \\ ${ }^{1}$ School of Journalism and Communication, Hebei University, No. 180 Wusidong Road, \\ Baoding City, Hebei Province, China \\ ${ }^{2}$ School of Multimedia Technology and Communication, Universiti Utara Malaysia, \\ Sintok, Kedah, Malaysia \\ *Corresponding author, e-mail: mt0999@foxmail.com
}

\begin{abstract}
This article provided a historical background of the challenges faced in the course of Islamic education of Chinese Muslims in the context of social change. The researcher historically evaluated how social change reshaped the Islamic education of Chinese Muslims, and highlighted the influence of technical development on Islamic education in contemporary China. The available research indicated that since the 1980s, the challenges faced in the course of Islamic education of Chinese Muslims have gradually shifted from political repercussions to technological development. Due to the limited literature, the researcher called for more research on new media development, especially social media and Muslim minority groups in China. The researcher also proposed a research agenda for future studies.
\end{abstract}

Keywords: Islamic Education, Social Change, Chinese Muslims.

\begin{abstract}
Abstrak
Artikel ini memberikan latar belakang sejarah terkait tantangan yang dihadapi kaum Muslim China dalam konteks perubahan sosial. Peneliti secara historis mengevaluasi bagaimana perubahan sosial mengubah cara kaum Muslim China dalam menyebarkan Islam, dan menyoroti pengaruh secara teknis perkembagan Islam dalam masa kontemporer di China. Penelitian yang ada menunjukkan bahwa sejak tahun 1980-an, tantangan yang dihadapi dalam pembelajaran Islam bagi Muslim China telah berangsur-angsur bergeser dari ranah politik menuju perkembangan teknologi. Karena terbatasnya literatur, maka peneliti lebih banyak mengkaji tentang pengembangan media baru, terutama media sosial dan kelompok minoritas Muslim di China. Peneliti juga mengusulkan agenda penelitian untuk studi selanjutnya.

Kata Kunci: Pembelajaran tentang Islam, Perubahan Sosial, kaum Muslim China.
\end{abstract}

Copyright () 2018 Universitas Semarang. All rights reserved.

\section{Introduction}

The development of information and communication technology, especially social media development, reshaped the global learning landscape in the 21 st century, not only in the developed countries but also in the developing countries (McLoughlin \& Lee, 2010). However, studies on Islam and social media are very scarce and have been basically conducted by either sociologists or computer specialists (Hatab, 2016), with even less attention on the educational perspective. This study tries to understand how the Islamic education of Chinese Muslims developed in contemporary China, and how

Article History: Received January 23, 2018; Revised January 28, 2018; Accepted January 30, 2018; Published January 31, 2018 
the development of information and communication technology influenced the Islamic education of Chinese Muslims in the 21st century.

In this review article, the researcher evaluated the available research on the Islamic education of Chinese Muslims in China, and showed how social change impacted on same. The researcher tried to explain how regime change and political turbulence reshaped the Islamic education of Chinese Muslims in history. The researcher also evaluated the literature of the impact of information and communication technology development on education, in order to know how information and communication technology reshaped Islamic education in China.

The researcher found that Islamic education changed dramatically due to regime change, especially after the 1949 ascent of the Communist Party to power in China. Islamic education has been a constant casualty of political turbulence since then. In addition, since 1980, information and communication technology (ICT) development has involved education with increasingly greater depth, and ICT development has become the trigger factor for monumental change in education. However, the research on ICT development and Islamic education of Chinese Muslims in contemporary China has not been fully explored. We conclude this article with a brief research agenda that may inform future studies on ICT and Islamic education in China. There is crying need for ample research on the interphase between ICT and the minority Muslim community in contemporary China.

\section{Methodology}

In this study, the researcher discusses published journal articles and online sources which explore Islamic education in China and the ICT development involved in education. In this way, we get to know the current situation of Islamic education of Chinese Muslims and try to further investigate the development of Islamic education in contemporary China from the ICT development perspective. The search strategy for this review includes five steps. The first step involved searching academic databases, especially the Jstor database for literature using specific keywords. The key words "Islamic education" and "Mosque education" were used most often. The second step entailed double-checking by Google Scholar. For the purpose of this review, in the third step, the researcher selected articles that focus on Islamic education in China and ICT involvement in education. However, there are not many research articles related to Islamic education in China, and it is confirmed that studies on Islam and new media are very scarce (Hatab, 2016). As part of the fourth step, the researcher searched articles in the National Social Science Database of China using the key words “伊斯兰教育(Islamic education)” and “经堂教育(Mosque education)”. In order to ensure deep understanding of the research conducted on Islamic education in China, research articles on Chinese Muslim studies were also selected from databases which were mentioned above, including Google Scholar, as part of the fifth step. This means that the articles selected for this review paper are in two languages; English and Chinese.

\section{Result and Discussion}

1. Brief History of Islamic Education in China

The Islamic religion was introduced into China during the Tang Dynasty period. The earliest wave of Muslim immigrants from Arabia and Persia came to and settled in China during the reign of the Tang Dynasty, and their descendants and other converts 
became Chinese Muslims, with a significant population of them converting during the Yuan Dynasty (Gladney, 1987; Hu, 1993; Wang, Wise, Baric, Black \& Bittles, 2003). Islamic education in China was considered to have started from the 7th century with early Muslim inhabitants through family education. The basic Islamic knowledge, doctrines and Shariah law were taught by parents to their children. As a result, Islamic knowledge was maintained from generation to generation by family education from the 7th century to the late Ming dynasty, which was the budding stage of Islamic education (Ma, 2004; Li, 2008). Family education was the basic way for Chinese Muslims to maintain their Muslim identity.

Since the 7th century, Chinese Muslim had developed Mosque education (Jing Tang Jiao Yu经堂教育) as the basic and main Islamic education system in China. The Mosque education system was set up at the time of the juncture of the Ming and Qing dynasties by Hu Dengzhou (1522-1597), on his return from a journey to Mecca. In the context of the Muslim scholars, Islamic education had decreased significantly, given the late Ming Dynasty's policy of seclusion, which restricted the foreign scholars who came to China (Li, 2008, Ha, 2013) and the policy of forced Sinicization of Chinese Muslims (Ma, 1996; Armijo, 2008). During the Qing Dynasty, Mosque education was developed within three educational centers which were located in Shan Dong, Shan $\mathrm{Xi}$, and Yunnan, three provinces which nurtured many Imams who had rich knowledge of the Islamic religion (Ning, 1985; Li, 2008). These Imams translated many Islamic texts into Chinese, and contributed to the development of the Muslim communities.

It was widely accepted that Mosque education was the beginning of the systematic Islamic religious education of the Chinese Muslims. Mosque education was carried out in mosques and financially supported by ambient Muslim communities, which historically formed the concept of mosque-centered construction. Imams were recruited for the Muslim students, and they taught them basic Islamic knowledge. The purposes of Mosque education included educating Muslims and training Imams (Ning, 1985; Ma, 1996; Li, 2008; Ha, 2013; Wen \& Gao, 2014). However, due to the conflict between the Muslim minorities and the ruling class, the anti-Qing uprising by Muslim minorities in China in 1648, 1781, 1784 and 1856 occured, but failed due to the Qing government's brutal suppression (Bai, 1996; Ding, 2001). These situations caused the gradual decline of Mosque education in the 18th century (Ning, 1985; Ma, 2004). Mosque education has more than four hundred years of history and still survives in contemporary China, while continuing to play an important role in the Muslim community.

In the turbulent times of the late Qing Dynasty and the early Republic of China, the Chinese Muslims developed modern schools to fulfill the needs of the modern talents of the Muslim society of China, and the schools provided modern education and Islamic religious education as well (Allès, 2003). In these schools, the syllabus of the modern education part was similar to that of the national education system, and basic Islamic education was added. These modern schools contributed to the prosperity of the media and associations of the Muslim society. By the end of the 1940s, there were more than four hundred primary schools, dozens of middle schools and several normal schools (Ning, 1985). The Chinese Muslims developed an almost complete modern education system at that time. The new form of education system of the Chinese Muslims contributed to the prosperity of the media and associations of the Chinese Muslim community. These media and associations played an important role in the education of Muslims, cross cultural communication and the anti-Japanese War effort. However, these modern schools have been the constant casualties of the turmoil of war in the 19th 
and 20th centuries (Ma, 2009; Liu, 2014). Modern Islamic education and the media both functioned as the social development boosters of the Muslim community.

After eight years of civil war, the Communist Party took power in China. The communist ideology was set up as the only accepted ideology, and based on this ideology, education was no longer an autonomous social institution. It became part of the Chinese Communist Party (CCP)-dominated State for the promotion of the political and ideological development of the Chinese people and society. Education became an instrument of social control (Tsang, 2000) to maintain political control. The Constitution of the People's Republic of China, and the Education Law of the People's Republic of China were reconstructed towards the discourse of the Chinese national educational system.

During the reconstruction of the Chinese national educational system, hundreds of modern schools of the Chinese Muslims were forced to merge with the national education system, which strictly separated religious education from public education, and kept political study as the central task to instill the students with communist ideals (Tsang, 2000). Subsequently, the modern Islamic education system of the Chinese Muslims was destroyed totally, and Islamic education was restricted to Mosque education. Furthermore, during the anti-religion political movement in the 1950s, religion was criticized as a way which oppressed the people, and in the ten-year Cultural Revolution Movement from 1966-1976, it was propagandized that religion is the opium of the people, and the Chinese Muslims suffered an outlawing of their religion (FitzGerald, 1967; Wan \& Li, 2005; Armijo, 2008; Israeli, 2012; Li, 2017). Essentially, Islamic education was suspended in Muslim Communities since 1958 till 1978, when the Chinese government implemented the reform policy.

After 1978, the Chinese government started to the implement the reform and opening-up policy, which created a more relaxed social environment. The relaxed social environment inspired a religious revival in Chinese society. Since then (Chan, 2004; Israeli, 2012), the Chinese Muslims slowly rebuilt or reopened their mosques, in which they could pray together again, and later restarted Mosque education. The Chinese government also established several Koranic Institutes (jingxueyuan经学院), as the government supported public Islamic education institutions. At the same time, many more private Arabic or Sino-Arabic schools, as well as many institutes which provided Islamic education were set up to fulfill the need for Islamic education in the Chinese Muslim communities. These private Arabic or Sino-Arabic schools can be found in Ningxia, Gansu, and Yunnan provinces, which have large Muslim populations. After graduating, many students go for further studies in foreign Islamic countries.

A part from these formal Islamic education types, many different types of informal or non-formal Islamic education models were developed based on Mosque education to fulfill the need of Muslim communities, such as the preschool programmes, after-school and summer school programmes for youths, evening and weekend programmes for adults, and day-time programmes for the elderly (Armijo, 2008). There are also a certain number of Chinese Muslim students who studied in college or university-organized non-public classes for Islamic education. These students form non-public Muslim student associations to promote and organize Islamic education classes, and encourage the practice of Islam and other religious activities (Armijo, 2008). These informal education systems were highly dependent on the surrounding mosques and Muslim communities. In conclusion, Islamic education in China acclimatized itself to the changing social context and struggled for its development. 
2. The Challenges Faced by Chinese Muslims in the Course of Islamic Education

2.1. Political Turbulence is the Overriding Challenge

Political turbulence was the main challenge faced by Chinese Muslims in the course of Islamic education. Dating back to the 17 th century, the political context of the Ming Dynasty was the trigger factor for the call for Mosque education. The Ming Dynasty's policy of Sinicization forced the Chinese Muslims to adopt Chinese surnames, dress like Chinese, and speak Chinese (Ma, 1996; Armijo, 2008). In addition, with the Sea Ban policy, the Chinese Muslims gradually could not speak the Arab or Persian language anymore, lacked Islamic knowledge, and could not recruit foreign Muslim teachers. The Mosque education system even developed a written system which mixed Chinese characters with Arab and Persian characters, named Xiao'erjing (Li, 2013). This special written system highlighted the struggles of the Chinese Muslims for their Islamic education system within the overwhelmingly influential non-Muslim Chinese society.

In the late Qing dynasty, the government lost political control of the country, and Western civilization started to influence the Chinese society. The Chinese Muslims developed the modern school educational system, which provided modern education and Islamic religious education as well (Allès, 2003). But due to the ascendance of the Communist Party to power, these modern schools were forced to merge with the Chinese national education system, and the Islamic religious education system was cut out of it. The Islamic education system was then restricted to Mosque education. However, the Mosque education system suffered after 1949 due to pressure from many political movements. During the anti-religious movement in 1950 , religion was criticized as a way of oppressing the people, and in the ten-year Cultural Revolution Movement from 1966-1976, it was propagandized that religion is the opium of the people, and the Chinese Muslims suffered an outlawing of their religion. Their mosques were defiled, closed or destroyed, and their Imams were persecuted, imprisoned and even killed (Wan \& Li, 2005; Armijo, 2008; Israeli, 2012; Li, 2017). Essentially, Islamic education was suspended in Muslim Communities until 1978, when the Chinese government implemented the reform policy.

After 1978, the Chinese government started to implement the reform and openingup policy, while creating a more relaxed social environment. The relaxed social environment inspired a religious revival in Chinese society then (Chan, 2004; Israeli, 2012). Meanwhile, the previous crackdown had caused the lack of educated Imams in the Chinese Muslim community. The Chinese Muslims slowly rebuilt or reopened their mosques, in which they could pray together again, and later restarted the Mosque education system.

In addition, apart from the China Koranic Institution which was set up in 1955, the Chinese government also established nine Koranic Institutes (jingxueyuan经学院) around the country between 1983 and 1987 in Beijing, Urumqui, Shenyang, Xining, Lanzhou, Zhengzhou, Kunming, Hebei Province and the Ningxia Hui Autonomous Region. Nine of these Koranic Institutes were teaching in Chinese. Only one of them was located in Urumqui, the capital city of Xinjiang Uygur autonomous region, which was teaching in the Uygur language. These Koranic Institutes are fully funded and controlled by the Chinese government through the state's Central Religious Affairs Bureau (Armijo, 2008). In these Koranic Institutes, the curriculum includes 70 per cent religious courses, such as recitation, Quran, Hadith, Arabic language, grammar and basic knowledge of Islam; 20 per cent Chinese courses, such as modern Chinese 
language, writing, history and geography; and 10 per cent political lessons, such as the nationality and religious policy of the Party and politics of current events (Wan \& Li, 2005).

However, compared to the majority non-Muslims, the Chinese Muslims have a lesser chance of higher education. Table 2 presents the population and the number of colleges and universities of mainstream Chinese and Chinese Muslims. Compared with the 2852 colleges and universities for the 1.3 billion Chinese population, the 23 million Chinese Muslims only have 10 Koranic Institutes which can be considered to be at the same level with colleges and universities. In other words, 474 thousand Chinese people have one college and university to them, but a whopping 2.3 million Chinese Muslims have one college and university to them for their Islamic education. The educational institutions for Chinese Muslims are extremely insufficient.

\begin{tabular}{|c|c|c|c|}
\hline categary & population* & $\begin{array}{c}\text { number of } \\
\text { college and } \\
\text { University }\end{array}$ & $\begin{array}{c}\text { population for per } \\
\text { college and university }\end{array}$ \\
\hline chinese & $1,339,724,852$ & $2852^{* *}$ & 474,406 \\
\hline $\begin{array}{c}\text { Chinese } \\
\text { Muslim }\end{array}$ & $23,142,104$ & 10 & $2,314,210$ \\
\hline
\end{tabular}

Table 1. The population and the number of colleges and universities of mainstream Chinese and Chinese Muslims (*Source: National Bureau of Statistics of China, 2010; **Source: The Ministry of Education of the People's Republic of China, 2016)

In addition, the number of recruited students of these Koranic Institutes is unbelievably low. The first Koranic Institute was China Koranic Institute, which was set up in 1955, but closed from 1965 to 1980, and from 1981, it started recruiting students again, as gleaned from the website of the Chinese Islamic Association. The number of the graduated students and number of current students could not be found. From 1955 to 1965, only 173 students graduated from the China Koranic Institute. There were no students in the Beijing Koranic Institute and Hebei Koranic Institute. Only 5 Koranic Institutes disclosed their current student number on the website of the Chinese Islamic institution, and they were 855 in total in 2012. Only 3 Koranic Institutes disclosed their graduated student number on the website of the Chinese Islamic institution, and they were 1946 in total in 2012.

Considering that there are more than 23 million Muslims in China, the number of students of these 10 Koranic Institutes is extremely small (see the Table 2). It reflects that the response of the Chinese Muslim community to these Koranic institutes was far from warm, given that these Koranic Institutes are fully controlled by the government. 


\begin{tabular}{|c|c|c|c|c|}
\hline Koranic Institute & $\begin{array}{l}\text { founding } \\
\text { time }\end{array}$ & $\begin{array}{l}\text { Current } \\
\text { student }\end{array}$ & $\begin{array}{l}\text { Graduate } \\
\text { student }\end{array}$ & website \\
\hline China Koranic Institute & 1955(1981) & & $\begin{array}{l}173(1955 \\
-1965)\end{array}$ & $\begin{array}{l}\text { http://www.chinaislamnet. } \\
\mathrm{cn} / \mathrm{indexh} . \mathrm{html}\end{array}$ \\
\hline Beijing Koranic Institute & 1986 & No student & & \\
\hline Shenyang Koranic Institute & 1982 & & & \\
\hline Xinjiang Koranic Institute & 1987 & 160 & 709 & \\
\hline Ningxia Koranic Institute & 1987 & & & \\
\hline Qinghai Koranic Institute & 1985 & 60 & & \\
\hline Hebei Koranic Institute & 1992 & No student & & \\
\hline Lanzhou Koranic Institute & 1984 & $400+$ & 799 & http://www.lzjxy.cm/ \\
\hline Kunming Koranic Institute & 1987 & 160 & 265 & $\underline{\text { http://www.kmii.com.cn/ }}$ \\
\hline Zhenzhou Koranic Institute & 1985 & 75 & & \\
\hline Total & & 855 & 1946 & \\
\hline
\end{tabular}

Table 2. The student number of the Koranic Institutes (Source: Chinese Islamic Association, 2017)

These Koranic institutes could not fulfill the need for Islamic education in the Chinese Muslim community, therefore more and more private Islamic schools were set up. Most of these Islamic schools were named Arabic or Sino-Arabic schools. There is no exact idea of the number of these private schools in the whole of China, but there are around twenty such private Islamic schools in Yunnan, Henan, Ningxia and Gansu province (Allès, 2003), while some of these schools have hundreds in student enrollment numbers. These private Islamic schools educated a large number of Muslim youth. However, even after many years of development and the efforts made, the private schools which provide Islamic education remain on a very low pedestal, and some have even deteriorated (Allès, 2003). Those private Islamic schools were ignored by the Chinese government, but were supported by the Chinese Muslim communities.

Mosque education in the Xinjiang Uygur autonomous region was restricted by Chinese government policy. Since 1958, mosques in China were closed due to the political movement, and after 1978, those mosques gradually reopened after the implementation of the reform and opening-up policy in China. The Mosque education gradually restarted after interruptions of more than twenty years (Wan \& $\mathrm{Li}, 2005$; $\mathrm{Li}$, 2017). There are almost 40,000 mosques in China, including almost 25,000 mosques in the Xinjiang Uygur autonomous region (Chinese Islamic Institution, 2015). However, since the 1990s, the Chinese government has applied a more strict policy in the Xinjiang Uygur autonomous region to restrict Islamic development in the area, in the name of anti-terrorism. According to these policies, an Imam is allowed to teach only one or two students and only with the backing of the Bureau of Religious Affairs and of the local authorities (Allès, 2003). It caused the decline of Mosque education in the Xinjiang Uygur autonomous region, and in this area there are at least 6 Muslim minority groups. There is very limited Islamic education in the Xinjiang Uygur autonomous region. 


\subsection{Social Structure is Another Destructive Challenge of Islamic Education}

The Mosque education system almost fully depends on the surrounding Muslim community; physically, financially and spiritually. However, the Chinese Muslim communities are seriously fueling disintegration among themselves (Ma, 2012). For instance, during the old days, the Chinese Muslim community resided together and wass strongly integrated in its localities. Since the Tang Dynasty, the Muslim residents developed the Mosque-centered communities, which have positively contributed towards maintaining their Muslim identity and Muslim culture.

However, after 1949, the structure of community construction in China was strongly influenced by what can be loosely translated into "system of unit". This system allows people with similar demographic attributes such as profession, occupation or place of work to reside together. The implication of such practice is that, a Muslim who is often a minority in China might find him/herself living among a pool of other colleagues and not among fellow Muslims. Furthermore, the reconstruction of old cities which often results into the erection of new and expensive buildings has been another reason for Chinese Muslims to live apart and afar from each other. Subsequently, when the Muslim minorities couldn't afford the new structures, they are forced to relocate into other communities (Ma, 2012). As a result, the mosques became lonely islands, with limited Muslims living around them. The Mosque education system lost its backbone, and it lost the support of the Muslim community.

2.3. Information and Communication Technology Development is a New Challenge

The Information and Communication Technology development affected Islamic education at deeper levels, and from different perspectives. Traditional Islamic education continues to have a strong influence in Africa, the Middle East and Asia (Houtsonen, 1994), and many researchers paid more attention to or highlighted traditional Islamic education and its associated developments in the new era (ElwellSutton, Arafat \& Isserlin, 1980; Latham \& Hopwood, 1983; Tibenderana, 1985; Giladi, 1987; Zaman, 1999). Since the 20th century, modernization has deeply influenced the social culture all over the world, especially the developing countries, and traditional Islamic education has faced many challenges in modern times.

Since the colonial times, traditional Islamic education in the developing countries has been influenced by Western education. The new schools differed in terms of content, organization, and culture from the existing Islamic institutes of higher learning. In this context, the scholar argued that the new schools were used as a means of transmitting and preserving indigenous Islamic culture (Herrera, 2004). The negative influence of Western education on the transmission and preservation of Islamic culture has also been discussed.

Modernization influenced many indigenous cultures, and influenced the meanings made of Islam in the new era. However, the Muslim society had a slower and ambivalent response to the scientific development which started from the West from early times (Livingston, 1996). Modernization created diverse societies all over the world, far from monolithic, and almost all the countries became multi-religious, multiethnic and multicultural. This international context also shaped Islamic education in developing countries, such as through some internationally funded programs to improve the quality of education, in which more value was given to democracy and tolerance in Islamic schools in Indonesia (Pohl, 2011). Islamic education has thus been influenced by many factors at home and abroad.

Jurnal The Messenger, Vol. 10, No. 1, January 2018, pp. 1-13 
The Muslim education of the minority Muslim groups has different functions, such as shaping the Muslim identity, and the role of the complex spaces for new forms of meaning making (Fataar, 2005). However, these different functions were influenced by the new concepts which originated in Europe such as democracy, civil society and others. In this context, some issues related to Islamic education also captured the researcher's interest, such as gender equality (Mehran, 2003), modernization and globalization involved in Islamic schools and higher education (Lukens-Bull, 2001; Waghid \& Smeyers, 2014). The internal conflicts between the Muslim minority and nonMuslim majority shaped the education of the Muslim minority (Milligan, 2003). The traditional Islamic education in the Muslim world faced many challenges due to the rapid change of the international order.

Based on his empirical study in Egypt, Cook (2001) concluded that a heavy majority of his respondents required more Islamic education and subject teaching from the Islamic perspective. They want the education system to preserve their Islamic integrity and help them feel confident about their Islamic religion. In the Islamic education system in Indonesia, the participation by teachers in madrasahs is increasing, but the participation by parents is still low, showing that the Islamic schools in Indonesia which adopted the new school-based management are far from being successful (Parker \& Raihani, 2011). These two cases represent the Islamic education in traditional Muslim countries in modern times; on the one hand, the common people look forward to the proper Islamic education; on the other hand, the Islamic education system seeks to be molded by the modern times.

As the main route of Islamic knowledge acquisition, traditional Islamic education has been influenced by technology development from the very early times. As Robinson (1993) emphasized, the impact of the technology revolution of the Gutenberg-invented movable type printing press is huge on the Islamic education of South Asia. The printing press changed the systems for knowledge transmission, shook the status of the Ulama, and moreover spurned the second revolutionary technology; electronic technology, which began to impact on the Muslim religious experience. Robinson was unable to foresee the third revolutionary technology; the internet and internet-based information technology, and its impact on Islamic education in contemporary society.

The media and religious education need to be researched deeper theoretically and practically. For a long time, religion was overlooked in media research and was considered to have played only a private role in society, while having no role to play in public or national life. In spite of this 21 st century notion, religion not only plays a significant role in the formation of social identities and the modern public sphere, but is also highly involved in international and regional affairs. Though not only for "religious awakening", the younger generation brought up with no tradition of faith are actively seeking or creating their own religions or spirituality. However, also for "religious revival", religion has become a significant element in post-colonial national rebuilding in a range of countries in Africa, Asia, Latin America and the Middle East. In today's globalized world, religion plays an increasingly important role in the economic, political, and cultural development in developing countries and developed countries as well. This situation became more complicated since the development of new media and its deep involvement in religious development.

At the end of the 20th century, the media industry became an independent institution in the society, and they do not only present or report on religious issues, but also influence the authorities of religious institutions. In addition, in the situation of 
national catastrophes such as occurred on September 11, 2001 in the USA and the Asian Tsunami in 2004, the media not only provided information but also served as a kind of psychological support for their audiences.

Given that the media is full of disseminated images of Islam and Muslims in the American media since September 11, 2001 (9/11), Hatab (2016) highlighted that the new media challenged the classical aura of male religious scholars who traditionally controlled the interpretation and production of religious knowledge. At the same time, he called for more research on the global Muslim community in different languages and on many "global" topics.

The biggest issue that needs to be of concern to the Chinese Muslims who wish to acquire Islamic religious knowledge through new media is the media environment in China. Currently, the media in China can be divided into three categories: traditional media, Internet media and Mobile media (Cui, 2013). Traditional media include newspapers, books, journals, radio, television and movies. Internet media include websites, search engines, social media, online games and so on, and any type of media related to mobile devices are defined as mobile media. Based on the philosophy of authoritarianism, all these media are mainly controlled by the Communist Party of China (CPC), Chinese government or companies which belong to or are invested in by the CPC or Chinese government (Luo, 2015) via ownership, sponsorship or censorship.

As the media of communist China, the most important role of all kinds of media in China is being "mouthpieces" of the Party and "propaganda tools" which are used for promoting the official communist ideology and consolidating the power of the state (Luo, 2015). In this context, there is no full freedom of speech and media in China, and all content is under censorship. Media censorship is crucial to guaranteeing the control of content, and the propaganda department of CPC is in charge of censorship of all media content. Censorship from the central and provincial propaganda department and self-censorship of media itself are also vital in this system.

The Chinese government keeps tight control over both traditional media and internet-based new media by using monitoring systems and firewalls, shuttering publications or websites and so on $(\mathrm{Xu}, 2014)$. The most powerful monitoring body is the Communist Party's Central Propaganda Department (CPD). In 2010, based on the concept of "Internet Sovereignty", all Chinese Internet users and foreign organizations and individuals in China were required by the Chinese government to abide by Chinese laws and regulations. In addition, Chinese Internet companies were required to sign the "Public Pledge on Self-Regulation and Professional Ethics for China Internet Industry", which entails strict rules $(\mathrm{Xu}, 2014)$ to avoid potential subversion of Chinese government authority.

The diverse ICTs are under the control of a new regulation which went into force on June 1, 2017; the "Regulation of Internet News and Information Services" issued by the Cyberspace Administration of China (CAC), which replaces the State Council Information Office to become the new regulator of online news services. This new regulation puts diverse new media under its control (Xinhua, 2017). All the new media, including social media and mobile apps are under the control of the new regulation.

3. A Research Agenda for Islamic Education of Chinese Muslims

Education has always been a major issue in maintaining the Chinese Muslim communities in an environment which is overwhelmingly non-Muslim (Allès, 2003). Based on the analysis of the literature, the researcher formulated a number of points for further research.

Jurnal The Messenger, Vol. 10, No. 1, January 2018, pp. 1-13 
1. There are many research foci on the traditional Islamic education of Chinese Muslims in China. However, it was morefocus on the educator or educational institution perspective. It is unclear how the students access and interpret the Islamic knowledge they get.

2. The existing research offers only very limited insights into Islamic education in the context of urbanization in contemporary China. However, urbanization can change both the social class and the population distribution (Ma, 2012). Urbanization changed the Muslim communities which traditionally surrounded the Mosques and were the strong backbone of Mosque education. So, the study of the urbanization influence on Mosque education should be a substantial part of future research on Islamic education.

There is a clear need for more comparative studies on ICT development and Islamic education in China. The development of ICTs facilitates information creation, consumption, communication and knowledge sharing, and it increased with the emergence of the Web 2.0 application. ICT became involved in the education sector decades ago in many countries including China. However, how ICT is involved in religious education is still unclear.

\section{Conclusion}

The Islamic education of Chinese Muslims in contemporary China faces many challenges, such as political, social, structural, and information communication technology (ICT) development challenges. These challenges made Islamic education in China become a more complicated phenomenon, which needs to be explored the more. ICT development, especially the development of social media, provides new opportunities for Islamic education in contemporary China. This paper highlights a number of future avenues for research on ICT and Islamic education in China.

\section{References}

Allès, E. (2006). Muslim Religious Education in China. China Perspectives [Online], January-February 2003. Online since 23 November 2006, connection on 07 May 2017, from http://chinaperspectives.revues.org/230

Armijo, J. (2008). Chinese Madrasas and Linkages to Islamic Schools Abroad. The Madrasa in Asia: Political Activism and Transnational Linkages. Farish A. Noor, Yoginder Sikand \& Martin van Bruinessen (eds). Amsterdam: ISIM/Amsterdam University Press

Bai, S.Y. (1996). Biographies of the Historic Figures from the Hui Ethnic Group. The Qing Dynasty. Vol. 33.

Chan, K.K. (2004). China's Socioeconomic Changes and the Implications for the Religion-State Dynamic in China. BYU Law Review, 2004 (2), Article 2.

Chinese Islamic Institution. (2015). The New Number and distribution of Mosque in China 2015. Retrieved on $2^{\text {nd }}$, July, 2017 from http://www.chinaislam.net.cn/cms/news/media/201503/03-8001.html

Cook, B.J. (2001). Islam and Egyptian Higher Education: Student Attitudes. Comparative Education Review, 45 (3) (August 2001), 379-411.

Cui, B.G. (2013). 2013 Blue book of Chinese Media. Beijing: Social Sciences Academic Press.

Ding, K.J. \& Yu, T. (2001). A Study on the Historical Relationship Between sufism and Mosque education in China. N. W. Minorities Research. 2001 (3), Total No. 30. 
Elwell-Sutton, L., Arafat, W.N. \& Isserlin, B.S.J. (1980). Middle Eastern Studies in British Universities and Work in Progress. Bulletin (British Society for Middle Eastern Studies), 7 (1) (1980), 55-57.

Fataar, A. (2005). Discourse, Differentiation, and Agency: Muslim Community Schools in Postapartheid Cape Town. Comparative Education Review, 49 (1) (February 2005), 23-43.

FitzGerald, C.P. (1967). Religion and China's Cultural Revolution. Pacific Affairs, 40 (1/2) (Spring-Summer, 1967), 124-129.

Gladney, D.C. (1987). Muslim Tombs and Ethnic Folklore: Charters for Hui Identity. The Journal of Asian Studies, 46 (3) (Aug., 1987), 495-532.

Ha, B.Y. (2013). JING XUE XI ZHUAN PU and Sharia Law. Studies in World Religions, 2013 (5), 126-135.

Hatab, W.A. (2016). Islam and Social Media: Attitudes and Views. Asian Social Science, 12 (5).

Herrera, L. (2004). Review: Education, Islam, and Modernity: Beyond Westernization and Centralization. Reviewed Work(s): Imperial Classroom: Islam, the State, and Education in the Late Ottoman Empire by Benjamin C. Fortna; The Modernization of Public Education in the Ottoman Empire, 1839-1908: Islamization, Autocracy, and Discipline by Selcuk Aksin Somel; Education, Religion, and the Discourse of Cultural Reform in Qajar Iran by Monica Ringer. Comparative Education Review, 48 (3) (August 2004), 318-326.

Houtsonen, J. (1994). Traditional Quranic Education in a Southern Moroccan Village. International Journal of Middle East Studies, 26 (3) (Aug., 1994), 489-500.

$\mathrm{Hu}$, Zh. H. (1993). The Hui Nationality in China. Yin Chuan: Ningxia people's Publishing House.

Israeli, R. (2012). Islam in China. Politics and Religion in Contemporary China, VI (2/2012), 251-268.

Latham, J.D. \& Derek Hopwood, D. (1983). Middle Eastern Studies in British Universities and Work in Progress. Bulletin (British Society for Middle Eastern Studies), 10 (1), 71-75

Li, X.Y. (2008). Analysis the Social Network construction of Hui From Educational Perspective. Journal of Tianshui Normal University, 28 (3), May, 2008

Li, L.A. (2017). The Religious Media are of Great Responsibility in Modern China. Retrieved on 8th, May, 2017, from: http://fo.ifeng.com/a/20170315/44554416_0.shtml

Liu, J.J. (2014). On Mosque education of the Hui Nationality in the Ming and Qing Dynasties. Journal Of Ningbo University (Educational Science Edition), 36 (1).

Li, N. (2013) Rethinking the Contemporary Islamic Education of Hui. Journal of the Central Institute of Socialism, 185 (5).

Livingston, J. M. (1996) Western Science and Educational Reform in the Thought of Shaykh Rifaa al-Tahtawi. International Journal of Middle East Studies, 28 (4/Nov., 1996), 543-564.

Lukens-Bull, R. A. (2001). Two Sides of the Same Coin: Modernity and Tradition in Islamic Education in Indonesia. Anthropology \& Education Quarterly, 32(3), 350372.

Luo, J. (2015). Media System in China: a Chinese Perspective. Int. Commun. Chin. Cult., 2 (1), 49-67. 
Ma, M.L. (1996). The formation and lessons of Modern New Education of Ethnic Hui and Salar. Journal Northwest Minorities University (Social Science), 2.

Ma, H. P. (2004). The Choice Faced by the Education of Hui Nationality in Modern Times. Guizhou Ethnic Studies, 24 (Genera1 No. 98).

Ma, J. (2009). Imam Ma Shan Ting in the Religious Dialogue. The Religious Cultures in the World, 1, 14-17.

Ma, X. J. (2012). An Elaboration of the Hui Mosque education in Helnan. Journal of Beifang University of Nationalities, 2 (Gen. No. 104).

Ma, X. F. (2012). Muslim Communities in Kunming : 1274--2000. N.W. Journal of Ethnology, 1 (Total No. 72).

McLoughlin, C., \& Lee, J. W. M. (2010). Personalised and self regulated learning in the Web 2.0 era: International exemplars of innovative pedagogy using social software. Australasian Journal of Educational Technology, 26 (1), 28-43.

Mehran, G. (2003). The Paradox of Tradition and Modernity in Female Education in the Islamic Republic of Iran. Comparative Education Review, 47 (3, August 2003), 269-286.

Milligan, J.A. (2003). Teaching between the Cross and the Crescent Moon: Islamic Identity, Postcoloniality, and Public Education in the Southern Philippines. Comparative Education Review, 47 (4, November 2003), 468-492.

Ning, W. (1985). From Mosque education to New Education Form of Hui--the Huge transformation of the Hui Education History. Social Sciences in Ningxia, 1, 27-29.

Parker, L. \& Raihani, R. (2011) Democratizing Indonesia through Education? Community Participation in Islamic Schooling. Educational Management Administration \& Leadership, 39 (6), 712-732.

Pohl, F. (2011). Negotiating Religious and National Identities in Contemporary Indonesian Islamic Education. Cross Current, September, 2011, 399-414.

Robinson, F. (1993). Technology and Religious Change: Islam and the Impact of Print. Modern Asian Studies, 27 (1), Special Issue: How Social, Political and Cultural Information Is Collected, Defined, Used and Analyzed (Feb., 1993), 229-251.

Tsang, M.C. (2000). Education and National development in China since 1949: Oscillating Policies and Enduring Dilemmas. China Review.

Waghid, Y. \& Smeyers, P. (2014). Re-envisioning the Future: Democratic Citizenship Education and Islamic Education. Journal of Philosophy of Education, 48 (4), 539-558.

Wang, W., Wise, C. Baric, T., Black, M. L. \& Bittles, A.H. (2003). The origins and genetic structure of three co-resident Chinese Muslim populations: the Salar, Bo'an and Dongxiang. Hum Genet, 113: 244-252.

Wan, ZH. X. \& Li, Q. (2005). Investigation of Mosque education in Lanzhou. Studies in World Religions, 2, 104-111.

Wen, F. \& Gao, Sh. G. (2014). On Evolution and Characteristies of Ningxia Hui Mosque education in Modern Times. Journal of Chengdu Normal University, 30 (10).

Xu, B. (2014). Media Censorship in China. Council on Foreign Relations. September 25, 2014. Retrieved on 13 May, 2017 from http://www.cfr.org/china/mediacensorship-china/p11515

Xinhua. (2017). China Issues Regulation on Online News Service. Xinhuanet. May 3, 2017. Retrieved on 2nd October, 2017 from http://news.xinhuanet.com/english/2017-05/03/c_136251798.htm 